\title{
Correlates and Consequences of Degree Purchasing among Canadian University Students*
}

\section{CÉLESTE M. BROTHERIDGE}

ESG - Université du Québec à Montréal

\section{RAYMOND T. LEE}

University of Manitoba

\begin{abstract}
This article develops the construct of degree purchasing as an instrumental orientation towards education in which students value education primarily as a vehicle for labour market participation rather than as an avenue for learning. This study of 188 Canadian university students found that a substantial proportion of students tended to be more interested in acquiring a diploma than the learning that it represents. Female students were more instrumentally oriented than male students, and younger students devalued learning to a greater extent than older students. Finally, a degree purchasing orientation was associated with poor study habits, the use of resistance strategies in the classroom, low positive affect, and poor course performance. Implications for higher education and suggestions for future research are discussed.

\footnotetext{
* An earlier version of this paper was presented at the annual meeting of the Administrative Sciences Association of Canada in Halifax in 2003. This research was partially funded by a President's Fund/ SSHRC grant from the University of Regina to the first author. The revision was prepared while the second author was on research leave at the Psychology Department, San Francisco State University. We are indebted to reviewers for their enormously insightful comments and suggestions.
} 


\section{RESUMÉ}

Cette recherche exploratoire tente d'analyser les prévalences de degree purchasing, une orientation instrumentale envers l'éducation. Les auteurs postulent que plusieurs étudiants conçoivent le diplôme universitaire comme un instrument permettant d'accéder rapidement au marché du travail sans faire les investissements requis en matière d'apprentissage. Cette recherche exploratoire réalisée auprès de 188 étudiants universitaires canadiens démontre que le degree purchasing se manifeste surtout parmi les étudiantes du sexe féminin et les étudiants moins âgés. En outre, les étudiants qui faisaient le degree purchasing avaient des mauvaises stratégies d'apprentissage ainsi qu'une faible motivation à apprendre.

\section{I never let my schooling interfere with my education.}

- Mark Twain

Although the institution of higher education has evolved over time, a widely shared and persistent belief has been that higher education serves purposes that go beyond the ordinary. It is a community in which all members engage in the pursuit of knowledge and the joy of learning to enhance their participation in, and indeed, enrich society (Parker, 2003). In this sense, education becomes a journey (Broadfoot, 1998) that is stimulating, engaging, and creative (Axelrod, 2000) and that builds one's capacity to adapt to and initiate change and to question assumptions and generate new ones (Ford, 1994). As stated by Aronowitz (2000, p. 161), higher education aims to "cultivate knowledge of the broadest possible kind to make learning a way of life that in the first place is pleasurable and then rigorously critical." Thus, universities should be "places where 'teachers gladly teach and students gladly learn" (Covington, 1997, p. 83).

Unfortunately, this may not reflect the reality of higher education today. In his lecture at the University of Manitoba on the state of undergraduate education entitled, "Researchers and Degree Purchasers," Paul Heyne (1997) argued that, "the vast majority of those who enrol in 
our universities today have done so to purchase a degree." He considered universities to be a nexus of two groups of individuals whose interests do not overlap - professors who are rewarded (psychically and otherwise) for undertaking useful research and students who simply want what the degree buys them - a ticket to a job - rather than the learning that it represents. Heyne further stated that this situation results in a contract in which "the faculty will give the students high grades and little work if the students will give the faculty decent teaching evaluations and otherwise leave them alone to pursue their research."

This perception is not unique. Others have noted that students tend to view their education as, "a stamp on one's life passport" (Lauter, 1995, p. 85), as, "qualification earning" (Thomas \& Anthony, 1996, p. 24), as, "a ticket of admission to a job" (Detrick, 2002, p. 57), or as, "something that 'happens' to them in return for paying tuition" (Dowling, 2000, p. 1). True, Winsor, and Pelton (2000, p. 441) observed that many students consider the university to be a, "diploma mill... [that offers] a 'meal ticket' for future employment." This metaphor seems fitting given that, "students may approach the university as they might a McDonald's drive-through window: selecting an option [at arm's length] with little thought to the process that created the Big Mac" (McMillan \& Cheney, 1996, p. 1). This view is encouraged by university ratings that are published in magazines, which take the form of "consumer reports, encouraging students and parents to look at higher education on just the same terms as they think about buying a new automobile or refrigerator" (Dowling, 2000, p. 2). Selecting an educational program becomes a matter of "winning the admissions game" (Johnston, 2002), the subtitle of the 2002 university rankings issue of the Canadian Macleans news-magazine.

A recent UCLA student survey (Ponzi, 1999) found that over 74 percent of their students were attending university because of its potential to help them find a job and/or earn more money. Likewise, an Ohio State University report on faculty perceptions of students (The Employed Student, 1997, p. 3) found that students were instrumentally oriented toward their education, fixated on the credential that it represents, concerned with obtaining a credential as easily as possible, and more likely to, "focus on ... the bare minimum that needs to be done to pass a 
course or get the desired grade." That some students attend universities for instrumental reasons has been evident since the dawn of universities (Perkin, 1991). Indeed, Perkin (1991) argued that it was the increasing demand for, "trained elites" (p. 171) that stimulated the growth of early universities. In recent times, the commodification of education (Renke, 2000) has reinforced the belief that the aim of universities is to facilitate the interface of students and potential employers (Gross, 1995), and the outcome of university training is a commodity with commercial value to be used as leverage for career advancement (Newson, 2000; Turk, 2000).

That students believe the primary mission of the university is to provide them with an employment meal ticket should serve as no great surprise (Ferris, 2002; Gross, 1995; May, 1991). The more profound question is how this orientation affects their motivation to learn. What is surprising is the dearth of research in this area. The present study examines the prevalence of a degree purchasing orientation and its association with elements of its nomological network. The latter analysis is particularly important given that such as orientation undermines the intrinsic desire to learn (Ames, 1992; Ferris, 2002; Simanek, 2000). This study develops a measure of degree purchasing, considers its relative prevalence in light of certain background correlates, and then employs path analysis to examine the relationship between this construct and study habits, student resistance, affectivity, and course performance.

\section{DEGREE PURCHASING ORIENTATION}

This study defines degree purchasing orientation as an instrumental view of education in which students value education primarily as a vehicle for labour market participation rather than as an avenue for learning. This orientation exists on a continuum; i.e., we should not dichotomously group individuals as degree purchasers or non-degree purchasers. Also, it does not directly represent a set of individual behaviours. Rather, it is an inner, psychological state and, thus, can be best gauged through self-report. This state is manifested in two primary attitudes: (a) that a degree is primarily a means to an end (Dore, 1976); i.e., its value lies in its consumption or use rather than its production; and (b) that getting through one's courses is valued rather than the learning they represent (Parker, 2003). The central 
theme is that education is viewed as product or end-state (a noun-something that is the object of action), not a process (a verb - the action itself). A student with a high degree purchasing orientation is less concerned with mastery than, "with being certified as having mastered. The knowledge he gained, he gains not for its own sake and not for constant later use in a real-life situation - but for the once-and-for-all purpose of reproducing it in an examination" (Thomas \& Anthony, 1996, p. 24).

Degree purchasing appears to be linked with performance goal orientation (Ames \& Archer, 1988; Ames, 1992), and extrinsic (Hayamizu, 1997) or external motivation (Ryan \& Connell, 1989). Students who have a performance goal orientation tend to be concerned with being judged as able; they show evidence of this ability by outperforming classmates or achieving success with little effort (Ames \& Archer, 1988). Students who adopt a performance orientation are likely to engage in instrumental behaviours (e.g., seek high grades with the least amount of effort) and, thus, are extrinsically motivated. In contrast, students with a mastery goal orientation seek to develop new skills, where the learning process is valued and mastery is dependent more on effort than ability (Ames \& Archer, 1988). Those who adopt a mastery orientation are likely to engage in behaviours that lead to inherent satisfaction and pleasure (e.g., learning to satisfy one's curiosity) and, thus, are intrinsically motivated (Covington, 1997; Deci \& Ryan, 1985). The following sections draw on the student motivation literature (Ames, 1992; Covington, 1997) to develop hypotheses.

\section{BACKGROUND CORRELATES OF DEGREE PURCHASING}

\section{Gender}

Research evidence suggests that male students are more likely to adopt an instrumental orientation toward their education than female students. Beutel and Marini (1995) found that among high school seniors surveyed from 1977-1991, females consistently were more likely than males to express concern and responsibility for the well-being of others, less likely to accept materialism and competition, and more likely to consider finding purpose and meaning in life to be extremely important. Young women 
continued to value intrinsic, altruistic, and social rewards of work more highly than did young men over the 14 years. These value differences persisted among college-age students (Boggiano \& Barrett, 1991).

In their survey of university students in Ontario, Vallerand, Pelletier et al. (1992) found that females demonstrated higher levels of intrinsic motivation than males. Kasser and Ryan's (1996) study of aspirations to achieve, "the American dream," found that female students were more likely to be intrinsically oriented than male students who were, in turn, more extrinsically oriented than female students. In a recent study of first year medical, nursing, and pharmacy students at a mid-southern US health sciences campus, Perrot, Deloney et al. (2001) also found that males were more extrinsically oriented than females. However, Cokley, Bernar, Cunningham, and Motoike's (2001) study of American students found no evidence that, "female students display a more self-determined motivational profile than male students" (Vallerand et al., 1992, p. 1015). Taken together however, the evidence suggests that males tend to be more extrinsically motivated than females, and, thus, the former are more likely to adopt a degree purchasing orientation than the latter. Hence, we predict that:

H1: Male students will have higher degree purchasing orientation than female students.

\section{Age}

Research evidence suggests the presence of differences in motivation as a function of age such that older students are less instrumentally oriented than their younger counterparts (Graham \& Donaldson, 1999; Jacobson, 2000; Perrot et al., 2001; Pourchot, 2000; Sedrak, 2003). Pourchot (2000) argued that differences in career stages likely cause older students to seek higher education to enhance personal growth (i.e., intrinsically motivated) and to be less concerned with instrumental outcomes than younger students. A comparison of traditional students (ages 18-22) and non-traditional students (ages 23 or older) found that the former had a higher extrinsic goal orientation than the latter (Jacobson, 2000). The latter tended to employ meta-cognitive learning strategies that focus on planning, 
implementing, and monitoring one's learning efforts. . Further, Justice and Dornan (2001) found that older students were more willing to adopt a comprehension-focussed approach to learning (e.g., "How does this topic relate to other topics discussed in this course?"); whereas younger students tended to adopt an evaluation-focussed approach (e.g., "Is this topic going to be covered on the exam?").

A recent study of students enrolled in physician assistant programs also found this negative relationship between age and performance goal orientation with the oldest cohort being mastery oriented (Sedrak, 2003). Along the same line, in a sample of first year health professional students, Perrot et al. (2001) found that students 24 years or older were more mastery oriented than younger students. Taken together, the evidence indicates that age is negatively associated with extrinsic motivation, and, thus, younger students are more likely to adopt a degree purchasing orientation than older students (Houle, 1974). Hence, we predict that:

H2: Younger students will have a higher degree purchasing orientation than older students.

\section{Program of Study}

Instrumentally oriented individuals tend be drawn towards programs of study that offer well-defined career paths such as business (Elm, Kennedy, \& Lawton, 2001) and engineering (Astin, 1992). Elm et al. posited that, just as people self-select into certain work organizations based on the fit of their values with the organizations' values, students self-select into certain programs of study based on their fit with their moral values. Moreover, the environment of the school/faculty in which students are educated may affect or reinforce their moral judgement. Elm et al. found that students with a masculine sex role orientation were more likely to major in business than in non-business areas, whereas those with a feminine sex role orientation were less likely to major in business than in non-business subjects. They found that business majors were marginally lower than non-business majors on moral reasoning, suggesting that business students may be socialized by their work organizations to be more instrumentally or extrinsically motivated.

Among a sample of first year graduate students, Schleef (2000) found 
that nearly half of the MBAs stressed that they were motivated by financial security, prestige, and high salary compared to only $11 \%$ of first year law students who stressed the same. The reason for why the MBAs were more instrumentally motivated may have to do with the desire to maintain the same socio-economic status as their parents. Such motivation is heightened when promotions and career advancements hinge on obtaining the degree. While some law students were extrinsically motivated, most were uncertain or vague on the reasons for studying law. However, a number of them were intrigued by the broad and potentially altruistic applications of law.

In a sample of undergraduate students enrolled in a teacher-training course, Ida (2003) found that the motivation of students with strong aspirations to be teachers was tied to the perceived usefulness of the course's learning content for employment and occupational practice. The motivation of students who were not geared toward the teaching profession consisted of interest in and self-development through task performance. These results indicate that students' motivation depended on the interaction between learners' goals and the content of the material being learned. Based on the above discussion, we predict that:

H3: Students enrolled in professional programs have significantly higher mean levels of degree purchasing orientation than students in other programs.

\section{OUTCOMES OF DEGREE PURCHASING ORIENTATION}

The construct of degree purchasing suggests that students who are strongly oriented are unlikely to be actively engaged in learning. Specifically, they are: (a) less likely to invest time, effort, and thought in developing a meaningful understanding the material; (b) more likely to resist demands placed upon them in the classroom; (c) more likely to develop negative attitudes; and, as consequence of the foregoing, (d) are less likely to demonstrate effective learning.

Study practices can be understood by examining the depth of understanding that is developed and the study methods that are employed by students. As stated by Schmeck, Ribich, and Ramanaiah (1977, p. 415), elaborative methods of processing information reflect an 
attempt to engage in deep learning in which, "the learner delves into the subtle nuances, meaning, and personal relevance of new information by thinking about it." Thus, elaborative methods require that students become engaged with the material and, in general, put a great deal of effort and thought into understanding it. This is in contrast to shallow learning in which the focus is on a superficial memorization and regurgitation of the materials.

Students' study methods are also likely to vary depending on their orientation towards education. In particular, those intrinsically motivated to learn the material are more likely to engage in the study methods traditionally associated with academic success such as adopting a regular study schedule or making detailed notes. Research indicates that students who are intrinsically motivated tend to put more effort into studying and processing information, employ more effective learning strategies, and use deep cognitive processes (Archer, 1994; Lepper, 1988; Miller, Greene, Montalvo, Ravindran, \& Nichols, 1996). In contrast, students who are extrinsically motivated prefer minimally challenging work that allows them to obtain desired rewards without much effort (Lepper, 1988). They tend to employ an economic ethic in which courses are simply hurdles to overcome on the way to employment (Aronowitz, 2000; Schleef, 2000).

Given their relative lack of interest in and attention to the learning process, students with a high degree purchasing orientation are likely to resist learning in the classroom setting. This may take the form of negligible class preparation and participation, disruptive behaviour, and the display of negative attitudes. There is evidence that an instrumental orientation toward higher education is positively associated with negative attitudes in the classroom and a desire to take courses known to be easy (Astin, 1992). Since such students tend to want spoon-feeding (rather than engagement in genuine learning), they are more likely to demand this in the classroom setting (Brownstein, 1998). This fits with Hayamizu's (1997) finding that, whereas people who are internally motivated are more likely to attribute success and failure to themselves, extrinsically motivated individuals are more likely to seek external sources of blame (see also Ames \& Archer, 1988). Disruptive behaviour or disengagement in the classroom may be a form of passive or maladaptive coping methods that Hayamizu found to be 
common among extrinsically motivated students. In contrast, internally motivated students tend to have more positive attitudes toward their learning than their extrinsically motivated counterparts (Archer, 1994; Miller et al., 1996).

A degree purchasing orientation may also be connected to students' emotional well-being. Whereas over-valuing extrinsic rewards has been associated with poor mental health and overall well-being (Kasser \& Ryan, 1993, 1996; Sheldon \& Kasser, 1995), intrinsic motivation has been associated with positive affect (Sheldon \& Kasser, 1995). This may be due to the fact that, whereas intrinsic motivation "can directly satisfy basic psychological needs for autonomy, relatedness, and competence" (Ryan, Chirkov et al., 1999, p. 1518), extrinsic goals "can provide only indirect satisfaction of these basic needs and may actually distract from or interfere with their fulfillment" (Ryan et al., 1999, p. 1518). This perspective is consistent with research on positive and negative affectivity (Watson, Clark \& Tellegen, 1988). These two constructs reflect a tendency to experience emotions such as interest, excitement, and pride (positive affectivity) or emotions such as anxiety, irritation, or hostility (negative affectivity). People with high levels of positive affectivity tend to be involved in their surroundings and take an active role in managing themselves; those with high levels of negative affectivity tend to interpret the world in a pessimistic manner (Brief, 1998).

Whereas an intrinsic motivation is positively correlated with achievement (Archer, 1992), an extrinsic motivation leads to reduced student performance (McMillan \& Cheney, 1996; Simanek, 2000). This likely occurs indirectly through poor student practices and classroom resistance behaviours that deter student performance. Thomas and Anthony (1996, p. 24) argued that, although such an orientation does not exclude the possibility of learning, it tends to result in little, "commitment from the learner to what is learned; [as such] it amounts not so much to drinking form the fountain of knowledge as merely gargling... [making] the learning experience 'ritualistic, tedious, suffused with anxiety and boredom, destructive of curiosity and imagination; in short, anti-educational' (Dore, 1976, p. ix)." Based on this review, we predict the following:

H4: Students' degree purchasing orientation will be negatively 
associated with their study practices. In turn, poor study practices will be negatively associated with course performance.

H5: Students' degree purchasing orientation will be positively associated with their classroom resistance behaviours. In turn, resistance behaviours will be negatively associated with course per formance.

H6: Students' degree purchasing orientation will be positively associated with negative affectivity and negatively associated with positive affectivity.

\section{METHOD}

\section{Participants}

Participants were 188 students with a mean age of 23.2 years $(S D=6.46)$, enrolled in a compulsory introductory organizational behaviour course at a university located on the Canadian prairies. Approximately 60 percent of the sample was male. Completion of this course was required by several faculties and, thus, drew students from a variety of programs including: management $(n=91)$, computer science $(n=5)$, kinesiology $(n=33)$, engineering $(n=23)$, arts $(n=8)$, education $(n=4)$, certificate programs $(n=20)$, and unspecified $(n=2)$. The students were offered a small credit toward their final grade in exchange for completing questionnaires over a one semester ( 13 week) period. They were informed that participation in this study was voluntary but not anonymous for those taking part since their final course marks would be linked with the questionnaire responses. To reduce the likelihood of response bias and for ethical reasons, they were assured that their responses would not influence their grades given that the instructor would access the questionnaires only after their final marks had been approved by the registrar.

\section{Measures}

Degree Purchasing Orientation. The measure of one's degree purchasing orientation was developed specifically for this study. It included a pool of seven items measured on scale of 1 (definitely not true) to 5 (definitely true; see Table 1). A factor analysis with vari-max rotation 
yielded two factors: factor 1 containing items relating to a 'learning as unimportant' and factor 2 containing items indicating that a 'degree is a ticket' for entry into the job market. In addition to these factors, a global measure of degree purchasing was formed by summing the seven items. To examine the factor structure of this measure and determine the appropriateness of employing a global measure of degree purchasing, confirmatory factor analyses were performed. Model A, in which the seven items were specified to load on their respective factors had a better fit to the data $(\square 2(13)=31.16, \mathrm{p}<.01$; GFI $=.96$; NFI $=93$; RMSEA $=.09$ ) than Model $\mathrm{B}$, in which all items were specified to loaded on one factor $(\square 2(14)=121.21, \mathrm{p}<.001 ; \mathrm{GFI}=.82 ; \mathrm{NFI}=73$; RMSEA $=.20)$. Given the superior fit of Model A, the subsequent analyses operationalized degree purchasing orientation as two variables: 'Degree as a Ticket' $(\square=.78)$, and 'Learning as Unimportant' $(\square=.78)$.

Learning Methods. The learning methods employed by students were measured primarily through the use of the Inventory of Learning Processes developed by Schmeck, Ribich, and Ramanaiah (1977). This inventory has yielded adequate test-retest reliability and scale internal consistency in previous research. The two five-point subscales included in this study were: (a) 12 items from the Elaborative Processing subscale $(\square=.81$; sample items: "When learning a unit of material I usually summarize it in my own words," and, "While studying I attempt to find answers to questions I have in mind"), and (b) 11 items from the Study Methods subscale $(\square=.80$; sample items: "I have regular weekly review periods," and, "I prepare a set of notes integrating the information from all sources in a course"). Procrastination in studying was measured by two items developed for this study, both of which were measured using a five-point response scale ( $1=$ definitely not true; $5=$ definitely true; $\square=$ .86). These items were: "I tend to do most of my studying or papers at the last minute (just before an exam or deadline)," and, "I would call myself a procrastinator."

Resistance Strategies. Student resistance strategies were measured with the 19-item Student Resistance Strategies inventory (Burroughs, Kearney, \& Plax, 1994). Students were asked how likely they would 
Table 1

Results of Factor Analysis of Degree Purchasing Items

\begin{tabular}{|c|c|c|c|c|c|}
\hline \multirow[t]{2}{*}{ Degree Purchasing Items } & \multicolumn{3}{|c|}{ Frequency $(\%)$} & \multicolumn{2}{|c|}{ Factors } \\
\hline & 1 or 2 & 3 & 4 or 5 & 1 - Learning & 2 - Ticket \\
\hline $\begin{array}{l}\text { 5. For me, each class is just one more step toward getting my degree. I'm not } \\
\text { especially interested in learning the material. }\end{array}$ & 65.1 & 22.3 & 12.6 & .80 & .16 \\
\hline 7. What I'm learning is less important to me than getting through a class. & 59.6 & 30.1 & 10.2 & .77 & .19 \\
\hline $\begin{array}{l}\text { 4. I don't particularly care about the content of various classes. I just want to } \\
\text { get through them. }\end{array}$ & 45.8 & 34.3 & 19.9 & .74 & .27 \\
\hline $\begin{array}{l}\text { 6. If I could - legitimately - just buy a degree (rather than having to take } \\
\text { classes), I would. }\end{array}$ & 66.3 & 16.9 & 16.8 & .74 & .07 \\
\hline 1. I am taking my degree because a degree is a ticket towards a good job. & 9.0 & 21.7 & 68.3 & .13 & .84 \\
\hline $\begin{array}{l}\text { 2. I am very interested in finishing my degree so that I can go out into the real } \\
\text { world and earn some money. }\end{array}$ & 14.4 & 21.1 & 64.5 & .11 & .83 \\
\hline $\begin{array}{l}\text { 3. My primary motivation in taking my degree is to get that piece of paper } \\
\text { (the diploma) that will give me access to some good jobs. }\end{array}$ & 19.9 & 28.9 & 51.2 & .34 & .77 \\
\hline Eigenvalue & & & & 3.31 & 1.31 \\
\hline
\end{tabular}

Rating scale: $1=$ definitely not true; $2=$ tends to not be true; $3=$ sometimes true; $4=$ tends to be true; and $5=$ definitely true. 
engage in a list of behaviours in response to an instructor's request or demand using a seven-point response-scale (1=extremely unlikely; $7=$ extremely likely; $\square=.84$ ). Sample items include: "I would resist by claiming that 'the teacher is boring," "I would challenge the teacher's authority by asserting: 'Do others in class have to do this?"' "I would rally up student support," "I would talk to someone in higher authority," and, "I'll get even by expressing my dissatisfaction with the teacher/course on evaluations at the end of the term."

Affectivity. State affect was measured with Watson et al.'s (1988) PANAS. This 20 item five-point ( $1=$ very slightly or not at all; 5=extremely) measure asked students to rate themselves on the extent to which they "generally feel on an average day." This list included 10 feelings that measure positive affect (e.g., alert, interested, inspired; $\square=.85$ ) and 10 feelings that measure negative affect (e.g., irritable, hostile, distressed; $\square$ $=.85$ ).

Course Performance. Performance in the course was determined through the use of the final grades earned by the students based on the mean scores of four objective multiple-choice exams that were administered over the span of the semester and were electronically graded.

\section{RESULTS}

\section{Prevalence of Degree Purchasing Orientation}

The frequency data presented in Table 1 provide an indication of the prevalence of degree purchasing orientation for the sample. In particular, a mean of $41 \%$ of the students assigned a value of ' 3 ' or greater across the four Learning as Unimportant items, while a mean of $85 \%$ of them assigned a value of ' 3 ' or greater across the three Degree as a Ticket items. The pattern of responses suggest that, while on average nearly $60 \%$ of students believed that learning was of some importance, the overwhelming majority of students, nevertheless, felt that their degrees had instrumental values.

\section{Descriptive Statistics}

Descriptive statistics and zero-order correlations of the study variables are presented in Tables 2 and 3. Although the two dimensions 
of degree purchasing orientation were positively correlated, their pattern of relationships with the remaining variables indicates that Degree as a Ticket was a weaker predictor than Learning as Unimportant. This suggests that the latter may have mediated the relationship between the former and the endogenous variables. In other words, perceiving a degree as a ticket may have influenced study behaviours and performance because it first engendered a devaluation of learning. Other than the foregoing and the lack of a significant relationship between Learning as Unimportant and negative affectivity, the pattern of correlations was in the predicted direction. Learning as Unimportant was negatively associated with elaborative processing, study methods, and positive affectivity, and positively associated with procrastination and student resistance.

Among the endogenous variables, procrastination and effective study methods were negative correlated. An examination of the association between Learning as Unimportant with the individual items of the student resistance scale shows that a devaluation of learning was associated with: not seeing the need to prepare for class $(r=.24)$, not preparing for class $(r=.35)$, challenging an instructor's authority $(r=.20)$, inciting resistance from other students $(\mathrm{r}=.13)$, 'getting even' on student evaluations $(r=.14)$, and lying $(r=.31)$ or making up excuses $(r=.20)$ as a means of explaining poor performance. Learning as Unimportant was also associated with: low alertness $(r=-.24)$, activeness $(r=-.16)$, attentiveness $(r=-.25)$, enthusiasm $(r=-.31)$, interest $(r=-.43)$, and determination $(r=-.30)$.

\section{Hypotheses 1 to 3}

The results regarding the relationship between demographic variables and a degree purchasing orientation yielded mixed support for hypotheses 1, 2, and 3. A one-way ANOVA indicated that, although females had a slightly higher mean level of perceiving a degree as a ticket than males (3.75 versus 3.59 ), this difference was not significant. The former also had a higher mean level of devaluing learning than the latter ( 2.47 versus $2.18 ; F=4.53, \mathrm{p}<.05)$. This finding, that female students were more instrumentally oriented than male students, is the reverse of what was 


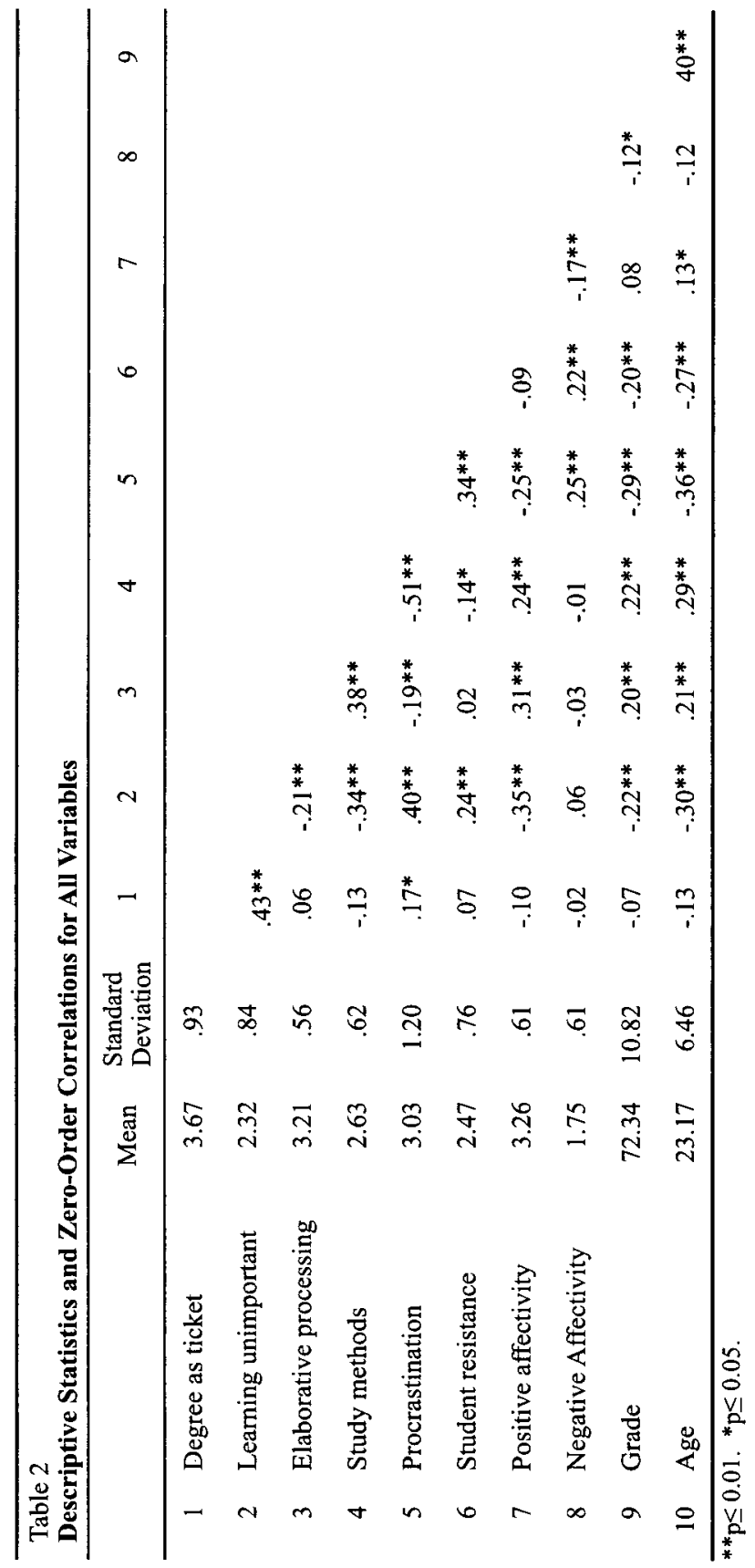


Table 3

Descriptive Statistics Organized According to Program of Study

\begin{tabular}{lll}
\hline \multicolumn{1}{c}{ Program } & Mean & Standard Deviation \\
\hline Degree as a Ticket & & \\
Business & 3.89 & 0.80 \\
Computer Science & 2.78 & 1.68 \\
Kinesiology & 3.37 & 0.86 \\
Engineering & 3.58 & 1.05 \\
Arts & 3.95 & 0.83 \\
Certificate & 3.30 & 1.07 \\
Education & 3.67 & 1.36 \\
Learning Unimportant & & \\
Business & 2.43 & 0.86 \\
Computer Science & 2.17 & 1.26 \\
Kinesiology & 2.34 & 0.74 \\
Engineering & 2.33 & 0.77 \\
Arts & 1.89 & 0.63 \\
Certificate & 2.02 & 0.90 \\
Education & 2.13 & 1.27 \\
\hline
\end{tabular}

hypothesized. As posited in $\mathrm{H} 2$, age was negatively correlated with both dimensions of degree purchasing, but only its correlation with devaluation of learning ( $r=-.30)$ was significant at the .05 level. An ANOVA employing Tukey post-hoc tests found no significant difference in degree purchasing given one's program of study. Thus, H3 was not supported. This non-significance was due in part to low statistical power, especially given the small sample sizes (i.e., $n s<10$ ) for several programs of study. Nevertheless, it is worth pointing out that the Arts students, specifically Economics, Anthropology, History, Psychology, and English majors, were most likely to perceive their degree as a ticket. 


\section{Hypotheses 4 to 6}

Path analysis employing AMOS 3.6 (Arbuckle, 1997) was used to examine the pattern of relationships predicted by Hypotheses 4 to 6 . As indicated in Table 4, the data yielded a close fit with the model, especially in comparison with a null model. Figure 1 shows that all but two of the parameter estimates were significant and supported the hypothesized paths. In particular, Degree as a Ticket predicted Learning as Unimportant which, in turn, predicted learning methods (elaborative processing, study methods, and procrastination), resistance behaviours, and positive affectivity. Learning as Unimportant did not predict negative affectivity. Elaborative processing, procrastination, and resistance behaviours all predicted grades. It appears that some of the potential variance in grades accounted for by study methods was explained by procrastination. A regression of Grades on Study Methods alone (i.e., without procrastination) yielded a significant effect $(t=2.45, \mathrm{p}<.05)$. The absence of a need to re-specify a direct path from 'Learning as Unimportant' or 'Degree as a Ticket' to Grades also suggests that their relationship was mediated by study behaviours.

Table 4

Goodness of Fit Indices

\begin{tabular}{lrccccc}
\hline & chi-square & df & p & CFI & NFI & RMSEA \\
\hline Path Model & 20.57 & 17 & 0.20 & 0.999 & 0.996 & 0.034 \\
Null model & 5104.66 & 45 & 0.00 & 0.000 & 0.000 & 0.775 \\
\hline
\end{tabular}

\section{DISCUSSION}

\section{Major Findings and Implications for Higher Education}

The present study found evidence that a substantial proportion of students may have adopted a degree purchasing orientation toward their education. Given its prevalence, it is all the more disturbing to find that such an orientation may undermine course performance through its impact on study habits and classroom behaviours (Simanek, 2000). Those with a strong degree purchasing orientation tended to resist learning by 


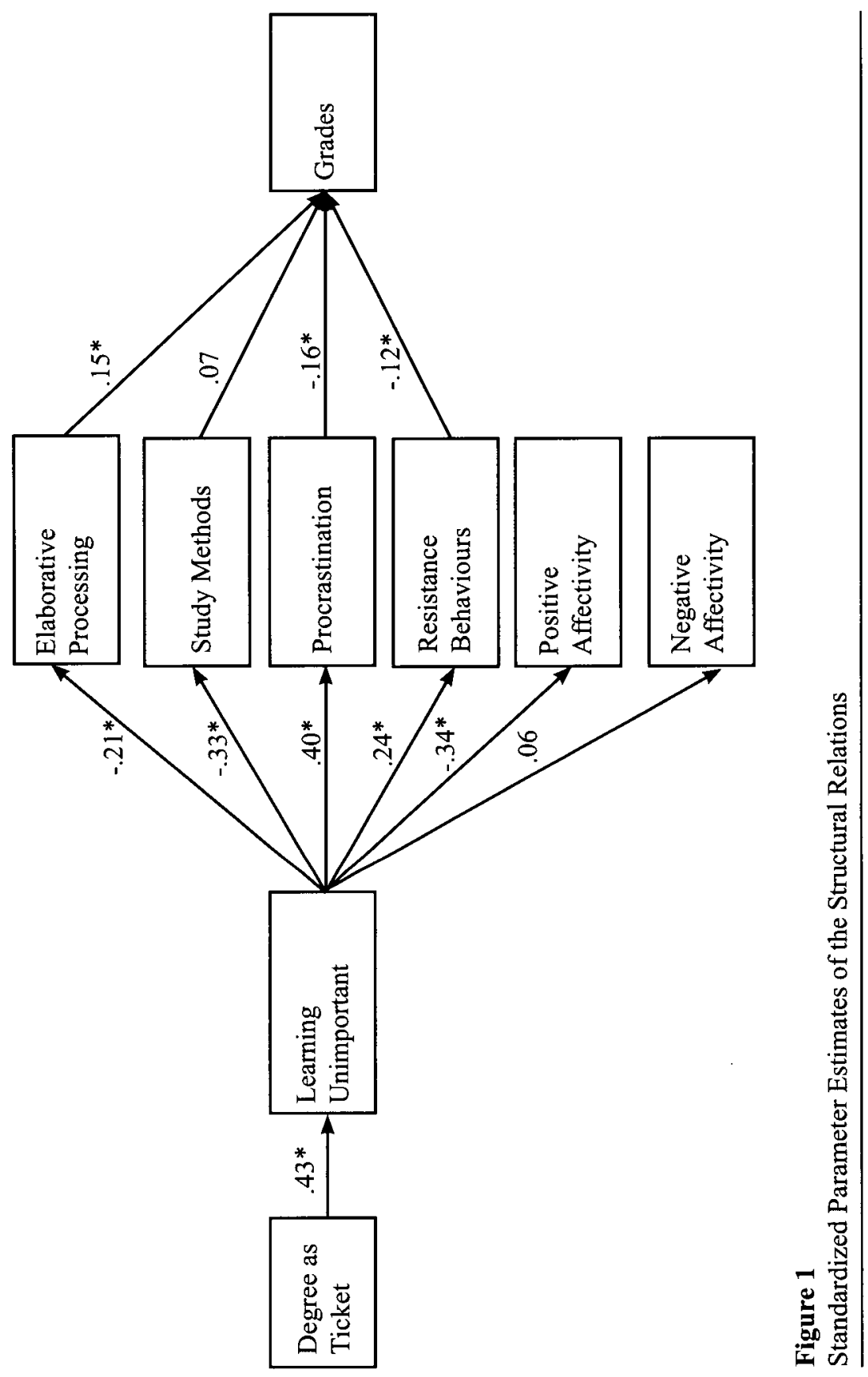


being passive learners (i.e., not preparing for or participating in class or making external attributions for poor performance), by acting out (i.e., challenging an instructor's authority, inciting resistance from others, 'getting even' on student evaluations), and by having low levels of engagement, attentiveness, enthusiasm, interest, and determination.

The tendency of females to devalue learning suggests that they may be tempted by extrinsic motivators (e.g., employment opportunities). As cognitive evaluation theory would suggest, the presence of extrinsic motivators may serve to undermine the intrinsic motivation to learn (Deci \& Ryan, 1985). The negative association between age and devaluing learning may be explained by meta-cognitive differences between older and younger students (Jacobson, 2000; Justice \& Dornan, 2001; McGucken \& Burke, 2002). Jacobson (2000) found that the older students relied more on meta-cognitive learning strategies that focussed on self-regulation and obtaining feedback.

That business majors had a high instrumental outlook on their education is to be expected in light of Elm et al.'s (2001) and Schleef's (2000) findings. What is surprising was that although the arts majors felt strongly their degrees were 'meal tickets,' they still felt learning itself had some importance. Indeed, their mean Learning as Unimportant rating was the lowest among all majors, whereas the business majors' mean rating was the highest among all majors. Although students from both majors recognized that degrees were critical for career success, arts students also realized the importance of learning certain skills even if the transferability of those skills may not be immediately apparent. Like some of the law students in Schleef's (2000) study, they may have come to the realization that if degrees open doors in the world of work, effort and mastery may open some doors wider and also open more doors ${ }^{1}$.

The phenomenon of degree purchasing is not new; tension has always existed between the ideal and pragmatic aspects of university education (Perkin, 1991). What is new is the extent of resources devoted to the privatization and commercialization of Canada's institutions of higher learning (Gross, 1995; May, 1991; Renke, 2000). Putting knowledge to work for the global village has created a potential clash with the aims of such institutions (True et al., 2000). To the extent that Canadian 
universities have been driven to become a more commercial, marketdriven endeavour, the students perceive themselves as 'educational clients' and their acquired education as a valued commodity that can be leveraged or traded like any other goods in the open market (Apple, 1998; Martin, 2002). How will this trend affect the students' sense of ownership in shaping their own education (Hechter, 1997; McGuckin \& Burke, 2002; Turk, 2000)? Will their intrinsic desire to learn be undermined by the lure of extrinsic motivators (Deci \& Ryan, 1985; Lepper, 1988)? What metacognitive strategies will students adapt as they mature and acquire broader life experiences in a commodified, culture (Apple, 1998)?

The propensity to commodify the university degree and its negative impact on study behaviours does not bode well for today's classroom (Renke, 2000; Ferris, 2002). It raises the possibility that disengagement and resistance will lead to behavioural mimicry and emotional contagion on the part of the remaining students. According to emotional contagion research, given their large numbers and the extent of social interactions typically found among students, degree purchasers are likely to poison the attitudes and behaviours of other students (Gump \& Kulik, 1997; Neumann \& Strack, 2000; Totterdell, Kellett, Teuchmann, \& Briner, 1998). It may be worth documenting how such contagion leads to the spreading of this orientation. Hence, attempting to inspire a genuine love of learning in courses where many degree purchasers are enrolled may be a daunting task indeed for teachers (Freedman, 1998; Parker, 2003). This is especially so for teachers who want, "to challenge students, to provoke new ways of thinking, to make students uneasy with what they have taken for granted...[For them,] the measure of success is not 'customer satisfaction' but intellectual growth" (Turk, 2000; p. 6).

However, just because students view their degrees instrumentally should not deter them from enjoying all the consumptive benefits of higher education (Hechter, 1997; Parker, 2003). Instead of being academic bystanders and passive recipients of knowledge (McMillan \& Cheney, 1996; True et al., 2000), they should take more active ownership and control in their educational experience (McGuckin \& Burke, 2002). Through transformative learning, skills and knowledge are rendered meaningful to the extent that the students can act upon them within the contexts of their 
lives (Axelrod, 2000) rather than just in course performance (Thomas \& Anthony, 1996).

\section{FUTURE RESEARCH}

Further research might seek to establish the validity and generalizability of the degree purchasing orientation measure. The temporal stability of the construct may be determined through analysis of the measure's testretest reliability. Research should be replicated with other groups of undergraduate and graduate students to determine the generalizability of our findings. The gathering of qualitative data would provide a richer description and understanding of the nature of the degree purchasing orientation. Also, consistent with the second half of Heyne's (1997) theory, research should investigate the intersection of degree purchasers and researchers. Specifically, they should examine the extent to which instructors themselves have adopted the kind of contract noted earlier in the paper; and how instructors address degree purchasing behaviour.

To the extent that degree purchasing orientation has detrimental effects on learning and the educational environment, discovering its etiology, spread, and changing dynamics is vital.

Interventions should then strive to reduce such an orientation. This may entail devising strategies to get students excited about learning (Gandz, 1997) by assigning projects that are intrinsically satisfying (Covington, 1997), by measuring achievement on the basis of individual accomplishments rather than relative to other students as emphasized by the practice of grading on a curve (Covington, 1997; Ferris, 2002), and by demonstrating "the social importance and personal rewards that flow from exploring 'the life of the mind"' (Axelrod, 2000, p. 204).

\section{Notes}

'We thank an anonymous reviewer for this insightful point.

Correspondence information: Céleste Brotheridge, Professeure. Département d'organisation et ressources humaines, École des sciences de la gestion, Université du Québec à Montréal. C.P. 6192, Succ. Centre-Ville, Montréal QC Canada H3C 4R2. Telephone: (514) 987-3000 poste 6540; Fax: (514) 987-0407; E-mail: grimard-brotheridge.celeste@uqam.ca 


\section{References}

Ames, C. (1992). Classrooms: Goals, structures, and student motivation. Journal of Educational Psychology, 84, 261-271.

Ames, C., \& Archer, J. (1988). Achievement goals in the classroom: Students' learning strategies and motivation processes. Journal of Educational Psychology, 80, 260-267.

Apple, M. W. (1998). The culture and commerce of the textbook. In L. E. Beyer \& M. W. Apple (Eds.), The curriculum: Problems, politics, and possibilities ( $2^{\text {nd }}$ ed., pp. 157-176). Albany, New York: State University of New York.

Arbuckle, J. L. (1997). Amos Users 'Guide Version 3.6. Chicago, IL: SmallWaters Corporation.

Archer, J. (1994). Achievement goals as a measure of motivation in university students. Contemporary Educational Psychology, 19, 430-466.

Aronowitz, S. (2000). The knowledge factory: Dismantling the corporate university and creating true higher learning. Boston: Beacon.

Astin, A. W. (1992). What matters in college? San Francisco: Jossey-Bass.

Axelrod, P. (2000). What is to be done? Envisioning the university's future. In J. L. Turk (Ed.). The corporate campus: Commercialization and the dangers to Canada's colleges and universities (pp. 201-208). Toronto, ON: Canadian Association of University Teachers/James Lorimer \& Company.

Beutel, A. M., \& Marini, M. M. (1995). Gender and values. American Sociological Review, 60, 436-448.

Boggiano, A. K., \& Barrett, M. (1991). Gender differences in depression in college students. Sex Roles, 25, 595-605.

Brief, A. P. (1998). Attitudes in and around organizations. Thousand Oaks, CA: Sage Publications.

Broadfoot, P. (1998). Quality standards and control in higher education: What price life-long learning? International Studies in Sociology of Education, 8, 155-180.

Brownstein, B. (1998). Discovering anewpedagogy for a new medium (preliminary version). Retrieved November 14, 2002, from home.ubalt.edu/bbrowstein/papers/ webteaching.

Burroughs, N. F., Kearney, P., Plax, T. O. (1994). Student resistance behaviors. In R. B. Rubin, P. Palmgreen, H. E. Sypher (Eds.). Communication research measures: A sourcebook. New York: The Guilford Press.

Cokley, K. O., Benard, N., Cunningham, D., Motoike, J. (2001). A psychometric investigation of the Academic Motivation Scale using a United States Sample. Measurement and Evaluation in Counseling and Development, 34, 109-119. 
Covington, M. V. (1997). A motivational analysis of academic life in college. In R. P. Perry \& J. C. Smart (Eds.). Effective teaching in higher education: Research and practice (pp. 61-100). New York: Agathon Press.

Deci, E. L., \& Ryan, R. M. (1985). Intrinsic motivation and self-determination in human behavior. New York: Plenum.

Detrick, G. (2002). Russell L. Ackoff (interview). Academy of Management Learning and Education, 1, 56-63.

Dore, R. (1976). The diploma disease: Education, qualification and development. London: George Allen and Unwin.

Dowling, W. C. (December 3, 2000). Why we should abolish teaching evaluations. The Daily Targum. Retrieved November 14, 2002 from www.bus.lsu.edu/accounting/ f...bley/abolishteachingevaluations.htm.

Elm, D. R., Kennedy, E. J., \& Lawton, L. (2001). Determinants of moral reasoning: Sex role orientation, gender, and academic factors. Business and Society, 40, 241-265.

Ferris, W. P. (2002). Students as junior partners, professors as senior partners, the b-school as the firm: A new model for collegiate business education. Academy of Management Learning and Education, 1, 185-193.

Ford, J. D. (1994). Management education: Shifting our assumptions. Journal of Management Education, 18, 212-226.

Freedman, S. E. (1998). Teaching, gender, and curriculum. In L. E. Beyer \& M. W. Apple (Eds.), The curriculum: Problems, politics, and possibilities ( $2^{\text {nd }} \mathrm{ed} ., \mathrm{pp}$. 230-244). Albany, New York: State University of New York.

Gandz, J. (1997). The death of teaching: The rebirth of education. Ivey Business Quarterly, 62(Autumn), 11-13.

Graham, S., \& Donaldson, J. F. (1999). Adult students' academic and intellectual development in college. Adult Education Quarterly, 49, 147-161.

Gross, B. R. (1995). The university and the media: Apologia pro vita sua with a defense of rationality. In M. Bérubé \& C. Nelson (Eds.), Higher education under fire : Politics, econmics, and the crisis of the humanities (pp. 126-148). New York : Routledge.

Gump, B. B., \& Kulik, J. A. (1997). Stress, affiliation, and emotional contagion. Journal of Personality and Social Psychology, 72, 305-319.

Hayamizu, T. (1997). Between intrinsic and extrinsic motivation: Examination of reasons for academic study based on the theory of internalisation. Japanese Psychological Research, 39, 98-108. 
Hechter, F. J. (1997). Influences on the academic achievement of undergraduate dental students. Dissertation Abstracts International Section A: Humanities \& Social Sciences, 57 (10-B), 6158.

Heyne, P. (1997). Researchers and degree purchasers: The classroom encounter. The Online Daily of the University of Washington. Retrieved December 10, 2002 from archives.thedaily. Washington.edu/1997/092997/heyne.htm.

Houle, C. (1974). The design of education. San Francisco: Jossey-Bass Publishers.

Ida, K. (2003). Autonomous motivation in college education majors: Ego-identity, achievement motivation, occupational readiness, and task-value evaluation. Japanese Journal of Educational Psychology, 51, 367-377.

Jacobson, R. R. (2000). Differences between traditional and non-traditional students on the Motivated Strategies for Learning Questionnaire. Dissertation Abstracts International Section A: Humanities \& Social Sciences, 61 (3-A), 879.

Johnston, A. D. (2002). The university crunch: Winning the admissions game. Macleans, November 18, 20-28.

Justice, E. M., Dornan, T. M. (2001). Metacognitive differences between traditional-age and non-traditional-age college students. Adult Education Quarterly, 51, 236-249.

Kasser, T., \& Ryan, R. M. (1993). A dark side of the American dream: Correlates of financial success as a central life aspiration. Journal of Personality and Social Psychology, 65, 410-422.

Kasser, T., \& Ryan, R. M. (1996). Further examining the American dream: Differential correlates of intrinsic and extrinsic goals. Personality and Social Psychology Bulletin, 22, 280-287.

Lauter, P. (1995). 'Political correctness' and the attack on American colleges. In M. Bérubé \& C. Nelson (Eds.). Higher education under fire: Politics, economics, and the crisis of the humanities (pp. 73-90). New York: Routledge.

Lepper, M. R. (1988). Motivational considerations in the study of instruction. Cognition and Instruction, 5, 289-309.

Martin, B. (2002). What did that degree do to you? Higher Education Review, 34, 67-73.

May, K. (1991). 'Misguided' policies driving out scientists. The Ottawa Citizen, 21 November, 1991, Al.

McGukin, C., \& Burke, D. (2002). Best evidence medical education in psychiatry training. Australasian Psychiatry, 10, 348-352. 
McMillan, J., \& Cheney, G. (1996). The student as consumer: The implications and limitations of a metaphor. Communication Education, 45, 1-15.

Miller, R. B., Greene, B. A., Montalvo, G. P., Ravindran, B., \& Nichols, J. D. (1996). Engagement in academic work: The role learning goals, future consequences, pleasing others, and perceived ability. Contemporary Educational Psychology, 21, 388-422.

Neumann, R., \& Strack, F. (2000). "Mood contagion": The automatic transfer of mood between persons. Journal of Personality and Social Psychology, 79, 211-223.

Newson, J. (2000). To not intend, or to intend not...that is the question. In J. L. Turk (Ed.), The corporate campus: Commercialization and the dangers to Canada's colleges and universities (pp. 183-194). Toronto: Canadian Association of University Teachers/James Lorimer \& Company.

Parker, J. (2003). Reconceptualising the curriculum: From commodification to transformation. Teaching in Higher Education, 8, 529-543.

Perkin, H. (1991). History of universities. In P. Altbach (Ed.), International higher education: An encyclopedia (Volume 1, pp. 169-204). New York: Garland.

Perrot, L. J., Deloney, L. A., Hastings, J. K., Savell, S., \& Savidge, M. (2001). Measuring student motivation in health professions' colleges. Advances in Health Sciences Education, 6, 193-203.

Ponzi, J. (1999). Survey says? Student complacency. The Claremont Institute. Retrieved November 14, 2002 from old.Claremont.org/publications/ponsi1/cfm.

Pourchot, T. L. (2000). Motivation toward personal development in adults' higher education participation. Dissertation Abstracts International Section A: Humanities \& Social Sciences, 60 (12-A), 4321.

Renke, W. N. (2000). Commercialization and resistance: Commercial takeover of secondary education. In J. L. Turk (Ed.), The corporate campus: Commercialization and the dangers to Canada's colleges and universities (pp. 31-50). Toronto: Canadian Association of University Teachers/James Lorimer \& Company.

Ryan, R. M., \& Chirkov, V. I., Little, T. D., Sheldon, K. M., Timoshina, E., \& Deci, E. L. (1999). The American dream in Russia: Extrinsic aspirations and wellbeing in two cultures. Personality and Social Psychology Bulletin, 25, 1509-1524.

Ryan, R. M., \& Connell, J. P. (1989). Perceived locus of causality and internalisation: examining reasons for acting in two domains. Journal of Personality and Social Psychology, 57, 749-761.

Schleef, D. (2000). "That's a good question!" Exploring motivations for law and business school choice. Sociology of Education, 73, 155-174. 
Schmeck, R. R., Ribich, R., Ramanaiah, N. (1977). Development of a selfreport inventory for assessing individual differences in learning processes. Applied Psychological Measurement, 1, 413-431.

Sedrak, M. M. (2003). The relationship between achievement motivation and student age among physician assistant students. . Dissertation Abstracts International Section A: Humanities \& Social Sciences, 64 (4-A), 1177.

Sheldon, K. M., \& Kasser, T. (1995). Coherence and congruence: two aspects of personality integration. Journal of Personality and Social Psychology, 68, 531-543.

Simanek, D. E. (2000). The decline of education 2. Retrieved November 14, 2002 from www.lhup.edu/ dsimanek/decline2.htm.

The employed student (November, 1997). A report of a forum cosponsored by the Academy of Teaching and Office of Faculty and TA Development. Retrieved January 20, 2003 from www.acs.ohio-state.edu/education/ftad/publications/academy-ftad. html.

Thomas, A. B., \& Anthony, P. D. (1996). Can management education be educational? In R. French \& C. Grey (Eds.). Rethinking management education (pp. 17-35). London: Sage Publications.

Totterdell, P., Kellett, S., Teuchmann, K., \& Briner, R. B. (1998). Evidence of mood linkage in work groups. Journal of Personality and Social Psychology, 74, 1504-1515.

True, S. L., Winsor, R. D., \& Pelton, L. E. (2000). The dilemma of teaching and learning in higher education. Marketing in a Global Economy Proceedings (pp. 440446).

Turk, J. L. (2000). What commercialization means for education. In J. L. Turk (Ed.), The corporate campus: Commercialization and the dangers to Canada's colleges and universities (pp. 3-14). Toronto: Canadian Association of University Teachers/James Lorimer \& Company.

Vallerand, R. J., Pelletier, L. G., Blais, M. R., Briére, N. M., Senecal C., \& Valliéres, E. F. (1992). The Academic Motivation Scale: A measure of intrinsic, extrinsic, and amotivation in education. Educational and Psychological Measurement, $52,1003-1017$

Watson, D., Clark, L.A., \& Tellegen, A. (1988). Development and validation of brief measures of positve and negative affect; The PANAS scales. Journal of Personality and Social Psychology, 54, 1063-1070. 